Александра Секулић ${ }^{1}$

Универзитет у Београду

Филолошки факултет

https://doi.org/10.18485/mks_knsjkk.2017.ch17

\section{РЕАЛИЗАМ ПРОТУМАЧЕН ДЕЦИ: ПОСТМОДЕРНО И РЕАЛНО У РОМАНУ ОПСАДА ЦРКВЕ СВ. СПАСА ГОРАНА ПЕТРОВИЋА}

Рад се бави наративним обликовањем и симболичком улогом реалног у роману Горана Петровића Ō̄caga uркве Св.Сйаса. Историјска стварност Петровићевог дела доследно је посредована различитим моделима фантастике, чиме се реално у њему вишеструко проблематизује и симболички трансформише. Премештање појмова из наслова Лиотаровог дела (заправо одабраних писама) Посиммоgерна йройумачена gеци, где и сам Лиотар у покушају филозофског, епистемолошог и поетичког одређења постмодерне полази најпре од новог схватања реализма, треба, дакле, да укаже на методички фокус овог рада. У контексу Петровићевог романа пратимо постмодерну редефиницију реалног која се очитује на дискурзивном, естетском и семантичком плану дела. Управо због препознатљиве културно-историјске позадине, која обухвата крај XII и почетак XIII века, а самим тим и низ догађаја од пресудне важности за српску средњовековну државу (опсада и рушење манастира Жиче, крсташки походи, дешавања на византијском двору), због целокупног реалног формално-стилски израженог језиком доминантних жанрова средњовековне књижевности

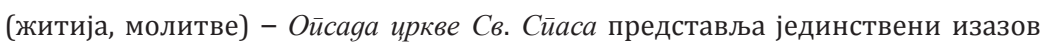
у схватању поетичких стратегија постмодерне. Стога протумачити реализам деци није симплификација проблема тумачења, као што то није ни била у Лиотаровим настојањима, већ потреба да се методичка полазишта у тумачењу сложеног појма реалног (који више није оно реално/стварно књижевне епохе реализма) усмере, дакле, ка поступној и свеобухватној анализи комбиновања различитих књижевноуметничких поступака и облика приповедања, затим ка увиђању симболичке улоге сна, који постаје једнако заступљена, релевантна стварност, и, најзад, разумевању приповедне фигурације аутентичне духовности постмодернизму готово опречне, али са Петровићевим романом сасвим постмодерно реализоване.

Кључне речи: реално, реализам, постмодерно, историјска стварност, сан.

${ }^{1}$ sekulic.aleks@gmail.com
У српској књижевности постоје писци које ћемо, без много оклевања, назвати мајсторима „приче и приповедања”. Горан Петровић је управо такав аутор, а Oйcaga иркве Cв. Cūaca такав роман - пример вишеструког мајсторства. Изазов читања овог романа обнавља се и умногостручава у сваком, рецимо то под знацима навода, и „наивном” херменеутичком контексту. У школи и на универзитету, пред малом и великом децом - Oūcaga uркве Cв. Cйaca отвара се у широком временском распону од средњег па све до пред сам почетак 21. века, обухватајући, дакле, рушење и обнову манастира Жиче, четврти крсташки поход и пад Византије и, најзад, НАТО бомбардовање Југославије 1999. године.

Поетичким укрштањем различитих књижевних традиција, уметничко-стилских поступака, облика приповедања и жанрова, Петровић ствара дело у ком се историја и прича срећу у Ђавољој вароши, географски посве одређено, симболички, изгледа, сасвим прикладно. Стварност овог романа, у ком се путује кроз време, у сновима се граде палате и жене се склањају како би безбедне од јаве изнеле трудноћу, док ће Симеон своме сину Сави открити да од византијског цара и васељенског патријарха све дарове одбије и прихвати само четири никејска прозора, у чему можемо ослушнути живописни дијалог поетичких стилизација топоса јављања у сну, а који се код Горана Петровића, као и код Милорада Павића, са чијим стваралаштвом умногоме комуницира, укључује у најшири контекст сневалачке фантастике, оне фантастике која је у постмодерној књижевности доживела свој врхунац, али која се може пратити од Калдерона до Борхеса. Стварност Oйcage uркве Cв. Cüaca је, пре свега, реално историје. Али то реално је од оног реализма за који Лиотар каже да га модернитет, без обзира на то којој епохи припада, никада не оставља без открића колико је реалност мало реална. Историјска проза постмодерног доба проблематизоваће саму могућност историјског сазнања, рекла би Линда Хачион, та историја, чак и када није историја у историјској прози, увек је конструкција, сплет дискурса, увек је и неизбежно нарайивна, написана као прича са којом се среће у роману Горана Петровића. Такав наратив, међутим, разликује се од, како би рекао Лиотар, мале ириче, која се бори за своје аутентично самоодр- 
жање наспрам Великог, наводно Универзалног, што га Историја континуирано и перфидно спроводи под паролом ослобођења, па тако и ослобођења Христовог гроба у контексту Петровићевог романа. А да ништа није тек онако и да је све саставак неке приче, како се каже у роману, симболички се обистињује управо у ономе што је реално.

Како методолошки приступити том и таквом реалном, како реализам протумачити деци, при чему парафразом Лиотаровог дела само желимо да нагласимо озбиљност једног таквог подухвата, који је толико филозофски, херменеутички и методички деликатан и обавезујући да никако не подразумева ауторитативни екс катедра приступ, а ни поједностављење овом одредницом gеца, којом алудирамо на ученике, много више на студенте и, дакле, интерпретаторе Oūcage цркве Св. Сйaca. Али, зашто су деца ипак потребна Лиотару, који је и сам био професор филозофије у средњој школи, а који каже како је детињство за филозофе чудовиште, али и њихов саучесник, јер показује да дух није дат, али да је могућ, зашто му је потребна та врста вишеструког почетка оличеног у детету и ученику, у тренутку када су све „велике приче" двадесетог века пребрзо сазреле и остариле са страховитим последицама по савремени свет, о томе, дакле, овде не можемо говорити, али треба споменути као још један, потенцијални рукавац ширег тумачења постмодернизма и постмодерног разумевања историје.

Међутим, зашто се реално историје објављује у Ойсаgи иркве Св. $C \bar{u} a c a$, у једној недвосмисленој духовности и, истовремено, крајње секуларној димензији власти и политичког ривалства, најезде Бугара и Кумана на манастир Жичу са једне стране и продор крсташа уз предводничку фигуру млетачког дужда Енрика Дандола у Византију са друге стране, да би се превасходно симболичка, а свакако хронолошка нит збивања еластично проширила до напада на Југославију 1999. године, до модерног рата? Зашто, дакле, прво треба разумети ово реално историје, које никада није стварно као такво, а нарочито не реалистично на начин реализма? То су питања којима се морамо посветити, јер обезбеђују далекосежно бављење и другим ауторима српске постмодерне прозе, као што су већ споменути Милорад Павић, Данило Киш, Борислав Пекић. Oūcaga цркве Св. Cūaca омогућава нам, дакле, да се приближимо и осетимо тешку стварност „властелина историје”, како би рекао Горан Петровић, у којој, пише у роману, „народи нетрагом нестају не стога што су имали одвише непријатеља" већ зато што „није било ничег да се сатвори о њима” (Петровић 2004: 234). Уважавајући начело методолошког плурализма, тумачење реалног онако како га маркира и демистификује оно постмодерно у делу Горана Петровића, мора поседовати динамику и интерпретативни опсег какав сам текст од нас захтева. Јер постмодерна флексибилност у комбиновању различитих поетичких дискурса, а која се огледа већ и на плану формалне организације романа који се састоји од седам књига у трајању од 40 дана, упућује нас на комплексну семантичку фузију историје и приче. Седам књига названих по небеским бићима (Серафими, Херуви-

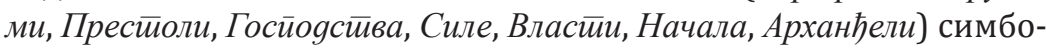
личком конотацијом и стилско-реторичким маниром библијског текста одражавају континуирани сукоб између принципа вере (или духовности у ширем смислу) и принципа моћи. Између ова два принципа, борећи се за властити опстанак, сместило се само приповедање. Јер, причама се прикупља, конзервира али и брани време, време целине постојања једног народа у историји која је, како се то каже у роману, „пажљиво удешена и образложена према интересу најмоћнијих држава, господара, трговаца и оних тирана који су постојали само ако се стално нешто историјски збива" (Петровић 2004: 295).

Сваки читалац Ō̄cage uркве Св. Сйaca осетиће ову врсту круцијалног збивања и, насупрот томе, онтолошко-поетичку упорност приче да буде написана, сачувана, пренета. Проблемско место у тумачењу романа, оно које ће око себе окупити мноштво његових семантичко-стилских димензија, управо је ова колизија између наратива и Историје, оне историјске реалности која би све приче да нивелише, онеми, и потчини увек одређеном центру моћи. А то се у роману може видети чак и у бризи оца Пајсија за своје пчеле. Када кроз прозор у Савиној катихуменији, онај што показује „садање на близину”, дакле, блиску будућност, угледа га- 
лоп бугарске и куманске војске и схвати да је непријатељ близу Жиче, Пајсије ће најпре панично дозивати своје пчеле, опомињући их да се сакрију и наставе да, како каже, „праше речи” (Петровић 2004: 53). Ово опрашивање речи, једна је од најсуптилнијих метафора од многобројних у делу Горана Петровића, а која треба да упризори непоколебљиво старање о културном идентитету колектива и која указује на опстанак једног народа кроз опстанак његове приче. Исто тако ће и хроничар, Никита Непознати, а који је, изгубивши свој прибор за писање, користио једно случајно нађено перо (а ми знамо да је то перо нестало са чувеног плашта од десет хиљада пера, тог чуда свеколиког знања и бесмртног живота око ког су се сукобили моћници, млетачки дужд Енрико Дандоло, бугарски цар Калојан и кумански вођ Шишман). Никита ће, дакле, тек што Латини провале градска врата, а док се из небеса спушта коноп избављења, остати на земљи, и животно и метафизички везан за текст, за предају речи, јер му се чинило, каже се у роману „ако ради личног избављења прекине ред или реч, да ће се истог часа прекинути и оно небеско уже” (Петровић 2004: 183). Годинама касније, у новој престоници Источног царства, у Никеји, један од најпознатијих ромејских хроничара Никита Хонијат, завршаваће своју чувену Истиорију, али иако се позамашно служи сведочанствима Никите Непознатог, нигде не спомиње име овог аутора. „Име је судбина”, пише Горан Петровић, а „историја је садржана од прећуткивања имена” (Петровић 2004: 185). И зато, тврди Лиотар, бити именован значи бити испричан. Свака прича, каже Лиотар, па и она привидно анегдотска, а у случају романа Горана Петровића сновида, фантастична или магијски реалистична, поново актуализује имена; „понављајући своју причу, заједница осигурава сталност и легитимитет свога света управо кроз понављање тог света у својим причама" (Liotar 1990: 51). Зато свака пчела оца Пајсија има властито име: Тихосава, Гроздана, Мрђица, Цвета...

„Самоидентификација једне културе увек пролази кроз овај диспозитив”. Стога „њено комадање”, каже Лиотар, „у случају колонијалне или империјалистичке зависности значи уништење културног идентитета" (Liotar 1990: 52).
Прича чува оно што би Историја да отме. Одричући нужност и достојанство имена, знака аутентичног идентитета Историја се много пута показала као, како би рекао Борхес, а непогрешиво осетио Киш, „историја бешчашћа”. Па кад отац Пајсије, у тренутку кад се на Жичу попну тама и дим куманских ватри запаљених од зечјих брабоњака, преда своје име љубимици, пчели Озрици, и упокоји се тек када види да је и последња пчела напустила опкољену кошару - овај детаљ није тек куриозум стваралачке маште, већ нам показује степен поетичке бриге за причу. А симболички ангажман те приче, персонификоване и у ономе што ће се краљу Милутину представити - „моје име је мало и да га чујеш не би га запамтио" (Петровић 229-230) - толико је, дакле, вишеструк и представља трансисторијски perpetuum mobile у роману у ком се годинама, и прошлим и будућим, тргује, док демонска фигура трговца Андрије Скадранина језди из века у век купујући и препродајући и време и животне приче. Дакле, то мало, толико мало да је незапамтљиво, али је ипак самопредстављиво онако како постмодерна уметност углавном и ради: она жели, како каже Лиотар, „да видљивим учини оно што се може мислити, а што је немогуће видети и видљивим учинити" (Liotar 1990: 23). Чак и у оним тренуцима када реално Историје опструише причу и када је краљу Милутину и његовој војсци заточеној на Ђавољим странама саопштено да се одатле не могу избавити, јер нема приче у којој они стижу да помогну Жичи, на месту тог „малог имена”, као Лиотарове „мале приче”, која се овде повукла пред незаустављивошћу Историје, на том месту, дакле, остаје неповређена воља за нарацијом, и као продужење врсте која приповеда и као метаприповедна свест. Услед такве свести, која ће, између осталог, обележити постмодерни роман, и када свему дође крај у Ойсаgи иркве Cв. Cūaca, а у целом поглављу се само каже да више нема о чему да се поведа, снажна симболичка потпора романа саморегенерише време свог симболичког трајања. Јер, каже Лиотар, прича је ауторитет. Зато ће се пред посету Андроника II Палеолога двору краља Милутина у Скопљу, сви дворјани трудити да се гостима приреди најлепши дочек и спреме најбољи дарови. Међу тим даровима, из краљеве ризнице право на трпезу послужиће многа 
„словенска сказанија”. Одушевљени, гости ће хвалисавог и лакомисленог краља Милутина замолити за још „по товар од свега”.

Пред упадљивом непромишљеношћу краља, који би да се све то одмах и спакује, само је оно мало, малога имена опрезно и будно, опомиње господара: „Нису све године родне”, рећи ће, „буде столеће и да више нема шта да се приповеда, а тада раба у животу држи да се прегризе једна те иста прича (Петровић 2004: 234). А колико је у овој мисли наталожено и историјског трагизма и ироније понављања видеће се у будућим годинама романа $O \bar{u} c a-$ ga иркве Св. Сūaca. Јер у будућности нас чека Богдан, син Филипе, жене василеуса Теодора Ласкариса, дете ношено у сну, а рођено за јаву модерног доба. У тим годинама, Богдан је, посвећеношћу каквом је отац Пајсије мотрио на своје пчеле, изучавао и трагао за птицама, опсесивно гледајући кроз прозоре и непоправљиво разочаран ониме што кроз њих види. У овоме дакле, препознајемо обрнуту, контрастну симболичку констелацију кључних мотива. Јер оно што ће пресећи петељку која манастир Жичу држи изнад земље управо је огромна, чудовишна птица, средњовековни пандан тројанском коњу, а која је дело Арифа, сараценског механика у Шишмановој служби. Исто тако, насупрот никејским прозорима у манастиру који су показивали оно што јесте, што је било, оно што ће бити, али и оно што ће се догодити у непосредној будућности, Богдан је виском, добијеним од зазидара Видосава, премеравао видела свога доба, установљујући увек неку померену перспективу, искривљену слику и лажну представу садашњости. Ово трагање за веродостојним призором доводило га је у не баш пријатне ситуације. Јер, како се каже у роману: „Нико не воли да му провирујеш кроз прозор, још мање да му указујеш на разлику између умишљеног и тачног. Са друге стране, власт без изузетка почива на изобличеном видику, али је само местимице, тек ту и тек тамо”, каже Горан Петровић, „понешто стварно стварно” (Петровић 2004: 194). То понешто увек је премало за оно што је људском бићу потребно, а увек сасвим довољно да изнова суспендује „мале приче”. Као што капитализам има, како пише Лиотар, невероватно дереализујућу моћ, тако су сви прозори у земљи 1999. године скретали поглед са Историје, дереализовали окна, која су заправо показивала да, каже се у роману: „Било како било, приче су се парале, живот се све мање састојао од приповедања, све је више личио на суве, јалове купице чаура, обмотане увртложеним калемовима историјских догађаја" (Петровић 1999: 272). Стога, ако се сада вратимо на ону исту причу, коју ће раб да прегризе у оскудно време, интензивније осећамо и њено онеспокојавајуће, иронијско тежиште: јер на самом крају романа читамо чланак из дневног листа Политике у ком се извештава да је на подручју општине Српски Брод нарушен еколошки систем, да је смањен број свих врста птица, неке од њих су потпуно нестале, супротно томе повећан је број пухова, инсеката, мишева и других штеточина који, као никада до сада, нападају и човека (Петровић 2004: 310). Једино што се може прегристи изгледа да је нова прича исте штете коју наноси Историја. Али управо приповедањем,

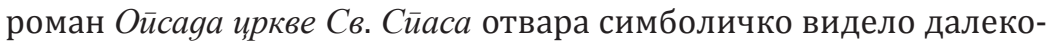
сежног домета.

Дело Горана Петровића говори језиком разбокорене фантастике, ненадмашне сликовитости, оно је синтеза искуства интеркултуралних преплета, државно-политичких веза и раскида, а преузимајући чудо као елемент средњовековне поетике, оно све време настоји да сачува чудо приче која храни, опомиње, провоциpa, која неће, како су то неком и учинили у роману, да буде бачена и уваљана у нишй . Адекватним методолошким вођењем, оним које увек „ослушкује” интерпретативне и теоријске „захтеве” иманентне самом делу, тумачење романа Oйcaga иркве Cв.Cūaca пружа могућности разумевања, колико и проблематизације поетичко-филозофских аспеката постмодернизма, нарочито његовог односа према историји и фикцији. Ако је у овом свету успех добити на времену, каже Лиотар, „мишљење онда има само једну ману, али такву да се не може исправити, оно омогућава губљење времена" (Liotar 1990: 135). Сходно томе можемо закључити да, ако је у овом свету под опсадом успех одржати предавање или час, роман Горана Петровића има само једну ману - он омогућава нелагоду сазнања да се од изгубљеног времена може добити прича, али да се од изгубљене приче не може добити време. 


\section{ЦИТИРАНА ЛИТЕРАТУРА}

Петровић, Г. Црква Св. Сйаса. Београд: Народна књига, 2004.

Hačion, L. Poetika postmodernizma: istorija, teorija, fikcija. - 1. izd. Novi Sad: Svetovi, 1996

Liotar, Ž F. Postmoderna protumačena djeci: pisma 1982-1985. - 1. izd. Zagreb: Avgust Cesarec, 1990.

\section{РЕАЛИЗМ РАСТОЛКОВАН ДЕТЯМ: ПОСТМОДЕРНИСТСКОЕ И} РЕАЛЬНОЕ В ОСАДЕ ЦЕРКВИ СВ. СПАСЕНИЯ ГОРАНА ПЕТРОВИЧА

В работе рассматривается повествовательное оформление и символическая роль реального в романе Горана Петровича Осада церкви Св. Спа$c a$. Историческая реальность произведении Горана Петровича опосредована различными моделями фантастики, благодаря чему в нем осуществляется многослойная проблематизация и символическая трансформация реального. На методическую направленность данной работы указывает заимствование понятий из заглавия книги Лиотара Постмодерн в изложении для детей (по сути, сборника писем), где и сам Лиотар, осуществля попытку философского, эпистемологического и поэтического определения постмодерна, исходит прежде всего, из нового понимания реализма. В романе Г. Петровича мы прослеживаем постмодернитское переосмысление реального, которое нашло свое отражение в дискурсивной, эстетической и семантической плоскости произведения. Именно по причине узнаваемости культурно-исторического фона, охватываю конец XII и начало XIII века, а тем самым и ряд исключительно важных, судьбоносных для сербского средневекового государства событий (осада и разрушение монастыря Жича, крестовые походы, события, происходившие при византийском дворе), а также благдаря совокупному реальному формально (стилистически) выраженному языком доминантных жанров средневековой литературы (жития, молитвы) - Осада церкви Св. Спаса представляет собой уникальный вызов для понимания поэтических стратегий постмодерна. Поэтому представление реализма в изложении для детей это не упрощение проблемы толкования (Лиотара тоже не стремился к этому) это попытка направить методические принципы толкованя сложного поня тия реального (а это уже не то реальное, которое было в эпоху реализма) к поступательному и всеохватывающему анализу комбинации различных литературно-художественных процессов и форм повествования, а затем к осознанию символической роли сна, который становится аналогичным образом представленной, релевантной реальностью и, наконец, к пониманию повествовательного оформления аутентичной духовности, практически противоположной постмодернизму, но в романое Петровича реализованной полностью в духе постмодернизма.
Драгана Д. Вељковић Станковић ${ }^{1}$

Филолошки факултет у Београду

удк:

https://doi.org/10.18485/mks_knsjkk.2017.ch18

$371.3:: 81^{\prime} 42$

\section{ЧОВЕК У ВЕЛИКОМ КРУГУ ПОСТОЈАҢА - КОГНИТИВНИ ПРИСТУП У РАДУ ЛИНГВИСТИЧКЕ СЕКЦИЈЕ}

Циљеви когнитивног методичког приступа у раду средњошколске лингвистичке секције јесу упознавање ученика са фигуративним значењима лексема које денотирају животиње, биљке, инаниматне и апстрактне ентитете, насталим на темељу реверзибилних појмовних метафора и метафтонимијских односа у оквиру великой ланияа, тј. великой круїа йосйојања. Будући да се метафора великої круїа йосйојеће̄̄ - у духу њеног општег експланаторног потенцијала - схвата као кохерентан изворни домен метонимијских саодношења која резултирају фино изнијансираним спектром карактеризације човека, знања која ученици треба стекну, захваљујући увиду у овакав начин преноса номинације, важна су за квалитативно унапређење активног вокабулара, побољшање изражајних потенцијала и за бољи увид у сагледавање и процењивање различитих људских особина путем паралелних процеса антропоморфизације и персонификације

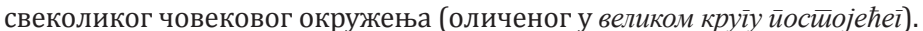

Кључне речи: примењена когнитивна лингвистика, семантичка деривација, богаћење активног вокабулара, лингвистичка секција.

1. Осека у лексикону говорника различитих узраста приметна је већ дуже време, те сигнализује многе актуелне, већ познате проблеме (непопуларност књиге, слабљење језичког осећања и изражајних могућности, популистички став према језичкој култури и др.), с којима нам се ваља суочити да би се лакше нашла решења, а њих је разложно тражити ангажујући се једновремено на теоријском плану и у наставној пракси српског језика као матерњег.

Стицање знања и добра мотивација за даљи рад не ограничавају се само на усвајање, повезивање и примену информација,

\footnotetext{
1 draganavs@yahoo.com

2 Овај рад је написан у оквиру пројекта 178006 Српски језик и његови ресурси који финансира Министарство просвете, науке и технолошког развоја Републике
} Србије 